\title{
ХУДОЖНІ ІНТЕРПРЕТАЦІЇ НАЦІОНАЛЬНОЇ ІДЕНТИЧНОСТІ ПИСЬМЕННИКАМИ «КАТОЛИЦЬКОЇ РУСІ» ДОБИ УКРАЇНСЬКОГО РЕНЕСАНСУ
}

\author{
Оксана Сліпушко
}

Доктор філологічних наук, професор,

Кафедра історії української літератури, теорії літератури та літературної творчості, Київський національний університет імені Тараса Шевченка (УКРАЇНА),

01004, Київ, бульвар Тараса Шевченка, 14, e-mail:

\section{Ольга Лісовська}

\section{Аспірант,}

Кафедра історії української літератури, теорії літератури та літературної творчості, Київський національний університет імені Тараса Шевченка (УКРАЇНА),

01004, Київ, бульвар Тараса Шевченка, 14, e-mail: shchelkunova2017@ukr.net

\section{PЕФЕРАТ}

Mema. Стаття присвячена дослідженню специфіки художніх інтерпретацій національної ідентичності письменниками «католицької Русі» доби українського Ренесансу, виокремленню характерних рис, які дають підстави кваліфікувати їх творчість як таку, в якій послідовно наголошується на українській національній ідентичності. Дослідницька методика. У дослідженні використано синтетичну наукову методологію, основану на різних методах інтерпретації фактів і текстів, зокрема порівняльноісторичного, філологічного, історико-літературного, культурно-історичного. Результати. Творчість письменників «католицької Русі» доби українського Ренесансу, зокрема Павла Русина з Кросна, Григорія Чуй Русина з Самбора, Симона Симоніда, Йосипа Верещинського, Мартина Пашковського, Георгія Тичинського Рутенця, Івана Туробінського Рутенця, Себастіяна Кленовича, Станіслава Оріховського, Івана Домбровського та ін. репрезентує систематичне підкреслення ними свого «руського» (українського) походження. Важливим аргументом на користь їх української самоідентифікації $є$ акцентування уваги на українській національній тематиці, актуалізація історичних подій у тогочасному суспільно-культурному просторі. Це була література, створена на межі двох культур і літератур - української та польської. Наукова новизна. У роботі вперше в історії української літературної медієвістики виокремлено специфіку художніх інтерпретацій національної ідентичності у творчості представників «католицької Русі», акцентовано увагу на їх ідентифікації з українським походженням і світоглядом, що виявляється у зверненні до національної історії, тлумаченні фактів культурно-суспільного простору доби Відродження, додаванні до свого імені прикладки Русин, Рутенець, Роксоланин на означення української ідентичності. Практичне значення. Матеріал дослідження може бути використаний для подальшого вивчення літератури українського Ренесансу, зокрема представників «католицької Русі», осмислення їх національної ідентифікації, студій над українсько-польським художнім контекстом кін. XV - поч. XVII ст.

Ключові слова: український літературний Ренесанс, Відродження, «католицька Русь», національна ідентичність, художні інтерпретації, українсько-польський літературний контекст. 


\title{
ARTISTIC INTERPRETATIONS OF THE NATIONAL IDENTITY IN THE WORKS OF «CATHOLIC RUS» WRITERS DURING UKRAINIAN RENAISSANCE ERA
}

\author{
Oksana Slipushko
}

\author{
Professor Doctor Habilitatus of Philology, \\ Department of Ukrainian Literature History, Theory of Literature and Literary Art, \\ Taras Shevchenko National University of Kyiv (UKRAINE), \\ 01601, Kyiv, 14 Tarasa Shevchenka Boulevard, \\ e-mail: oksana-slipushko@ukr.net
}

\section{Olha Lisovska}

Postgraduate student,

Department of Ukrainian Literature History, Theory of Literature and Literary Art,

Taras Shevchenko National University of Kyiv (UKRAINE),

01601, Kyiv, 14 Tarasa Shevchenka Boulevard,

e-mail: shchelkunova2017@ukr.net

\begin{abstract}
Aim. The article deals with artistic interpretations of the national identity in the works of «Catholic Rus» writers during Ukrainian Renaissance era. The aim of this study is to analyze the specific details that give a possibility to qualify the works of writers as a representation of Ukrainian national identity. Methods. It is used a synthetic scientific methodology based on different methods of interpreting facts and texts - comparativehistorical, philological, historical-literary and cultural-historical. Results. The works of «Catholic Rus» writers of Ukrainian Renaissance era - Pavlo Rusyn from Krosno, Mykola Husovskyi, Hrygorii Chui Rusyn from Sambor, Symon Symonid, Yosyp Vereshchynskyi, Martyn Pashkovskyi, Heorhii Tychynskyi Rutenets, Ivan Turobinskyi Rutenets, Sebastiian Klenovych, Stanislav Orikhovskyi, Ivan Dombrovskyi and others - represent the systematic accent on their «Rus» (Ukrainian) origin. An important argument in favor of their Ukrainian identity is the emphasis on the Ukrainian national theme. Scientific novelty. In this article, for the first time there has been investigated the specific of artistic interpretations of the national identity in the works «Catholic Rus» representatives. It is underlined their identification with Ukrainian origin and outlook. It can be noted from the interpretation of the national history, facts about Renaissance cultural and social space and adding Rusyn, Rutenets, Roksolanyn to their names for identifying Ukrainian origin. Practical meaning. The article is of great help to further studying of Ukrainian Renaissance literature, in particular the works of «Catholic Rus» representatives, their national identity comprehension, studies on the Ukrainian-Polish artistic context of late $15^{\text {th }}-$ early $17^{\text {th }}$ century.
\end{abstract}

Key words: Ukrainian literary Renaissance, «Catholic Rus», national identity, artistic interpretations, Ukrainian and Poland literary context.

Традиційно поняття національної ідентичності визначається як усвідомлення автором своєї приналежності до певної нації, народу. Доба українського літературного Ренесансу (кін. XVI - поч. XVI ст.) була епохою збереження національної ідентичності, незважаючи на те, що Україна не мала власної державності, входячи до складу Литовсько-Руської держави і Речі Посполитої, а мовою літератури була переважно латинь. Проте творчість представників цього періоду позначена акцентуванням уваги на власній етнічній, тобто русько-українській приналежності, зверненням до національної історії, проектуванням їі на тогочасний суспільно-політичний і культурно-літературний простори. Переважна більшість письменників цього часу належали до так званої «като- 
лицької Русі», зокрема Павло Русин із Кросна, Микола Гусовський, Григорій Чуй Русин із Самбора, Георгій Тичинський Рутенець, Іван Туробінський Рутенець, Себастіян Кленович, Станіслав Оріховський, Іван Домбровський та ін. Вони були католиками, проте, як наголошує В. Шевчук, «не забували своєї «солодкої рідної руської землі», неодмінно підкреслювали своє «руське», тобто українське, походження. Робили так і представники українсько-польської поезії С. Симонід, брати Зиморовичі, М. Пашковський, Й. Верещинський, А. Чагровський, С. Окольський, В. Кіцький, Ян Щасний-Гербурт та багато інших поетів, у творчості яких наскрізно проходить українська тема» [4, с. 70]. Bci вони відчували синівський обов'язок перед Вітчизною, зберігали їй відданість, не зважаючи на життєві перипетії. Їхня творчість перейнята глибоким гуманістичним світоглядом.

Окремі аспекти проблеми національної ідентифікації представників «католицької Русі» доби українського Ренесансу вивчаються у працях П. Кралюка, В. Литвинова, Д. Наливайка, Р. Радишевського, Оксани Сліпушко, Д. Чижевського, Людмили Шевченко-Савчинської, В. Шевчука, В. Яременка та ін. Проте специфіка художніх інтерпретацій національної ідентичності у митців «католицької Русі» не була предметом окремого наукового дослідження. Можемо говорити про елементи трактування цісї теми у працях названих учених. Натомість вона потребує окремої уваги, оскільки визначає новий вектор бачення літератури Відродження, іï межовий характер творення в контексті української та польської традицій.

Українська література доби Відродження формувалася на межі власної та польської традицій та ідентичностей. Ї̈̈ творцями були переважно вихідці 3 України, які послідовно наголошували на своєму етнічному походженні й ідентичності. Водночас усі вони вважали себе причетними до загальноєвропейського простору, його поетичного Парнасу. Представники «католицької Русі» були українцями римо-католицького віросповідання, поширюючи на теренах України, Білорусії, Польщі ідеї європейського гуманізму. Багато з них навчалися в європейських університетах, а потім виступили творцями латиномовної українсько-польської літератури. В. Литвинов зазначає, що «католицька Русь» мала доволі високу національну конфесійно-етнічну свідомість» [2, с. 350]. Це були люди 3 високою національною свідомістю, які ідентифікували себе українцями, наголошуючи на руському походженні. Багато з них брали собі відповідні псевдоніми, зокрема, Станіслав Оріховський-Роксолан, Георгій Тичинський-Рутенець, Іван Туробінський-Рутенець, Павло Русин, Григорій Чуй Русин із Самбора та ін. Визначальною рисою їх творчого світогляду був український патріотизм.

Фактично першим ренесансним автором став Юрій Дрогобич (справжнє прізвище Котермак). Будучи родом із міста Дрогобича, він завжди наголошував на своєму руському походженні. Вихованець Краківського і Болонського університетів, у 1481-1488 рр. обіймав посаду ректора останнього. Його «Прогностична оцінка поточного 1483 року» репрезентує гуманістичні тлумачення феноменів природи, особистості, Бога, поцінування людського розуму, його сили і можливостей. Насамперед автор закликає свого читача бути «прихиль- 
ним до книги» $[4$, с. 15]. В уявленні митця, національна ідентифікація виявляється у власному імені - Дрогобич. Павло Русин із Кросна (Кросненський) українсько-польський поет гуманістичного спрямування. Народився у містечку Кросно біля Перемишля. Називаючи себе Русином, підкреслював своє руське походження. Його руський дух і світогляд художньо виявляється у збірці віршів «Пісні» (1509 р., Відень). В. Литвинов називає його одним «із зачинателів культури Відродження в Україні» [1, с. 359]. Павло Русин репрезентував ренесансно-гуманістичну ідею про цінність людської особистості, іiі здатність завдяки індивідуальним якостям, зокрема доброчесності, освіченості, доблесті піднятися до богоподібності. Саме слово «русин» вважав «словом солодким», в якому концентрується для автора ідентифікація з Україною.

Поширення католицизму на теренах Русі-України було пов'язане 3 діяльністю ордену домінікан, характерною рисою якого був регіональний патріотизм, спроби створити незалежну від Польщі католицьку церкву в Україні. Домініканцем був Йосип Верещинський, родом зі Збаража. 31589 р. обіймав посаду єпископа Києва, всіляко сприяючи розвитку київської католицької церкви. $\mathcal{C}$ автором ряду проповідей, написаних у простому стилі та поетичних творів. У творі «Побудка його цісарської милості всього християнства, також до його королівської милості короля польського, так само до ясновельможного князя великого московського з метою піднесення святої війни спільною рукою супроти турків і татар» (Вільно, 1594) автор порівнює себе з пророком Ісайєю, утверджуючи ідею про єдність усіх християн як запоруку безпеки проти Туреччини. Свою національну ідентифікацію виявляє у тлумаченні історичних спогадів про боротьбу з турками у давніші часи, згадках про козаків. Він яскраво ідентифікує себе як українця, звертаючись до джерел виникнення українського козацтва, міркуючи про створення рицарської школи в Україні. Патріотизмом і любов'ю до України перейняті його згадки про князя Дмитра Вишневецького (Байду), якого називає «козаком бойовитим». У творі «Дорога певна до найшвидшого осадження в Руському краї пустельних земель рицарством королівства Польського» (1590) йдеться про заселення й захист України, яка втратила свою колишню велич і лежить у пустці. Автор закликає співвітчизників схаменутися, відродити колишню славу і велич. Національні проекти козацьких реформ репрезентовано у творі «Війську Запорозькому пресвітлий виказ як щодо виховання, так і щодо вічного забезпечення на Задніпров'ї» (1596). Загалом автор мислив Україну як вільну у складі Речі Посполитої. Вважав, що саме Україна повинна стати її центром і коронною землею. Йому належить ідея відродження великого Київського князівства і створення сильного козацького війська. Як наголошує В. Шевчук, Йосип Верещинський «відчував свою місію державотворця в Україні» [6, с. 189], декларуючи іiі, «бачив свій народ сильним, вільним і державним» [6, с. 189].

Григорій Чуй Русин із Самбора є новолатинським польсько-українським поетом. Вихованець Краківського університету, обіймав посаду ректора шкіл у Перемишлі та Львові, професора Краківського університету. Написав ряд латиномовних поем, еклог, панегіриків, зафундував жанр курйозного вірша - акровірша. Автор ряду поетичних творів, зокрема ідилій латинською мовою 
«Аминт» (1560), «Еклога» (1561), «Алексис» (1566). Оспівуванню муз і достоїнств предків - русів-українців, до яких відносить і себе - присвячені вірші «Вивід перший», «Вивід другий», «Вивід третій». Висловлював надію на мир між двома конфесіями i народами - українським і польським. Всіляко підкреслював те, що є українцем за походженням. Георгій Тичинський Рутенець був професором поетики і риторики у Краківському університеті. Автор твору «Поема про святу Варвару» (1537). Визначав свою приналежність до Русі як Вітчизни оспівуванням діянь Святої саме на українських землях. Усі згадки про себе супроводжував доданням до імені Рутенець. В українському дусі та стилі представлено опис Святої Варвари, що нагадує українську жінку.

Іван Туробінський (Туробіній) Рутенець обіймав посади професора і ректора Краківського університету. Автор латиномовних епіграм, у яких оспівувалися різноманітні теми і проблеми тогочасного українсько-польського життя. Будучи далеко за межами Вітчизни, висловлював тугу і жаль із приводу розлуки з нею, виявляючи при цьому повагу до їі традицій, захоплюючись славною історією. Себастіян (Севастян) Фабіан Кленович - українсько-польський поет, автор поем «Роксоланія» (1584) і «Звитяжство богів» (1587) латинською мовою. У «Роксоланії» прославляє Україну, іiї традиції, оспівує красу і багатства міст, сіл, звичаїв, легенд. У творі репрезентовано глибоке духовне споріднення автора з землею, яку він оспівує і прославляє. Його екскурси в історію свідчать про те, що автор міг читати якусь редакцію «Повісті врем'яних літ». Він уболіває, що історію його Вітчизни мало знають у Свропі. Звісно, що це погляд людини, яка народилася тут. Він щиро захоплюється красою рідної землі, використовуючи українські народні легенди і перекази. Себастіян Кленович хвалить русів за вірність православній вірі та традиціям предків. Найбільш імовірним $€$ те, що сам він був вірменського походження, з українсько-вірменського роду. Тому «зрозумілим стає його відверте відмежування від поляків, адже й справді: виходець із корінних польських земель, пишучи про Русь, ніде про поляків не згадує, не мислить Русі як складової частини Речі Посполитої. Що було б натурально в устах громадянина цієї держави, а говорить про Русь як про окреме етнічне тіло. Цю землю він називає рідною й хвалить православну віру, хоч сам за віросповіданням був католиком. Узагалі весь його опис Роксоланії вражає синівською відданістю й любов'ю до ії лісів, гір, міст, а передусім до іï осельців - русів, тобто українців» [6, с. 155-156]. С. Кленович прагне прославити Вітчизну в усьому світі. Твір перейнятий глибоким і щирим патріотизмом автора i загальноєвропейським гуманізмом, який цілком корелюється з тогочасним українським світоглядом. У творі репрезентовано осмислення української історії згідно з ренесансно-гуманістичними світоглядними настановами. Автор інтерпретує роль і місце українців та інших слов'янських народів у світовій історії, осмислюючи походження свосї нації. Він категорично критикує покатоличення українців, а хвалить їх за те, що вони пам'ятають і шанують традиції предків.

Феномен Матвія Стрийковського належить литовсько-білорусько-українсько-польському контексту. Він народився у Стрийкові, на Ленчицькій землі (сучасна Польща). Навчався у Падуї та Болоньї. України стосується його го- 
ловний твір «Хроніка польсько-литовська, жмудська і всієї Русі: Київської, Московської, Сіверської, Волинської, Подільської, Підгірської, Підляської і таке інше» (1582). Автор включає до складу Русі й Московщину, хоча акцентує увагу на українських територіях, розробляючи українську та литовську історії. Руський народ він називає славним, таким чином його виокремлюючи. 3 гордістю митець веде оповідь про слов'янських і литовських предків, наводячи яскраві віршовані вставки з історичним викладом. Білу і Чорну Русь називає він народами старожитніми, русів ототожнює з роксоланами. Стрийковський вважає поляків теж руським племенем, як і сербів. Князя Романа Галицького описує як лицаря, але симпатії автора загалом на польському боці. Князь Роман напав на ці землі, а Стрийковський є гуманістом, тому справедливим вважає обороняти рідну землю. Причиною занепаду руської держави вважає відсутність у ній згоди. У вірші «Про вибиття 25000 татар перекопських під Вишневцем, року 1512 , полякам і литвинам» описано одну 3 найвидатніших битв князя Костянтина Івановича Острозького. В. Шевчук пише, що «цей твір укладається в систему поглядів М. Стрийковського: згода панує, а незгода руйнує; і друге: коли захищається вітчизна - це свята справа, через що вона буде переможна» [6, с. 166]. Головна сила у цій битві - українська. Детально описано битву, місією котрої є захист рідної землі. Головний герой - князь Острозький - ідеальний тип воїна і полководця. Правомірно визначає В. Шевчук національну ідентифікацію М. Стрийковського, котрий «як людина і як митець почуває себе не поляком, не литвином, не русином, а таки громадянином Речі Посполитої, в якій об'єдналися три народи, і образним утіленням цієї держави постає у вірші з'єднане військо. Тобто поет - продукт державотворення свого часу» [6, с. 167].

Іван (Ян) Домбровський - католик-домініканець, представник київської шляхти, яка перейшла у греко-католицизм, автор історичної поеми «Дніпрові камени» (близько 1619 р.). Можна «вважати І. Домбровського продовжувачем традиції літератури «католицької русі» на терені самого Києва, адже головна думка його твору - відродження українського державотворення» [6, с. 264]. Виявом національної української ідентичності $€$ насамперед апеляції автора до української крові, звернення до історії українського народу. Митець репрезентує специфіку місцевого населення, наголошуючи на необхідності відродження Києва як колишньої столиці великої Києворуської держави, спадкоємиці давньої Скитії. На його думку, мосхи, тобто росіяни, з'явилися значно пізніше. Свою місію автор вбачає у поверненні давніх традицій свого народу, його державної пам'яті. Він художньо осмислює розповіді про київських, галицьковолинських, литовських князів. $Є$ представником католицької Русі, вважає своїм обов'язком служити рідній землі, а не Речі Посполитій. Твір сповнений авторської гордості за історичне минуле народу, прагнення переконати нащадків, що вони «із плоті геройської русів», звитяга і мужність яких відомі світові. Козацтво вважає прямим нащадком руських воїнів. Звернення до історичного минулого формує основу для відродження колишніх слави і величі. Наголошує, що населення Русі «візантійських обрядів тримається ревно од віку» [5, с. 202]. Своєю метою вважає патріотичне виховання українців, сприяння їх морально- 
етичному становленню. Він репрезентує Україну Європі, чітко ідентифікуючи українців із населенням Київської Русі.

Латиномовний поет Шимон Шимонович (Симон Симонід) народився у Львові, навчався у Краківській академії. Автор поетичних творів «Бич заздрості», «Елінопеан», віршів-треносів, збірки «Селянки». Його твори позначені яскраво вираженим українським колоритом. У польській літературі започаткував жанр українських пісень - «селянок». У книзі «Селянки» репрезентовано ідилічні твори на теми переважно з українського національного життя. У їх контексті бачимо прояви реального суто українського життя. Зокрема, географічні назви, описи звичаїв, побуту. Життя і побут українського народу репрезентовані у селянках XV «Чари» і XVIII «Женці». Ці селянки формують специфічну поетику, основану на синтезі античних мотивів і народних побутових українських.

Симон Пекалід (Пенкальський, Пенкаля) - українсько-польський поет народився біля Кракова, навчався у Краківській академії. Очевидно, що наголошував на своєму руському походженні, адже у «Книзі промоцій» про переведення у вищий клас, його названо русином. Потім прибув до Острога, де був придворним поетом князя Острозького. Можливо, брав участь у битві під П'яткою 1593 р. проти козацького гетьмана Криштофа Косинського. Автор поеми «Про Острозьку війну під П'яткою проти Низових [козаків]. Чотири книги, написані бакалавром мистцеві Симоном Пекалідом» (1600). Тут репрезентовано поетичний опис повстання козацького гетьмана Криштофа Косинського 1593 р. Автор оспівує Острог як видатний культурний осередок, прославляє рід князів Острозьких за їх внесок у розвиток національної культурної традиції. Себе він вважає причетним до тих справ, які вони роблять. Центральним $є$ питання єдності Руської землі, миру в ній, а не розбрату і розпаду, що осмислюється 3 патріотичних позицій. Історія роду Острозьких тут поступово трансформується в історію України.

Польсько-український поет Ян Щасний-Гербут називав себе представником українського народу, репрезентуючи при цьому високу національноетнічну самосвідомість. Виступав проти національного приниження українського народу, наголошуючи, що могутність Польщі можлива завдяки союзу 3 Україною: «Жоден розум, жодне насильство не може досягти того, щоб Русі не було в Русі. А що коли хтось захоче, щоб поляків не було у Польщі?» [5, с. 174]. $\mathrm{У}$ «Розмислі про народ руський» автор захищає права українців. Видатний представник католицької Русі Станіслав Оріховський родом із Премишля, навчався у Кракові, Німеччині, де зійшовся з Мартіном Лютером. А також студіював у Віденському, Падуанському, Болонському університетах. Свої твори підписував іменами Оріховський-Русин, Оріховський-Роксолянин. Оріховського називали в тогочасній Європі «рутенським Демостеном». Як наголошує В. Шевчук, «С. Оріховський послідовно означував своєю Батьківщиною Русь, хоч громадянином був таки Польської Держави» [6, с. 142]. Про своє руське походження написав у творах «Супліка до найвищого понтифікат Юлія III про схвалення взятого шлюбу», «Лист до Яна Франціска Комендоні про себе самого». Запереченню целібату присвячені його твори «Про закон целібату проти 
Сиріція», «Промова у справі закону про целібат», листи до Папи Юлія III, «Хрещення русинів», «Розрив з Римом». Говорячи про антиприродність цього закону, наводить біографічні відомості про себе, послідовно ідентифікуючи себе з Руссю-Україною. У державотворчих трактатах «Напучення польському королеві Сигізмунду Августу», «Квінкус, тобто Взірець устрою Польської держави», двоє слів «Про турецьку загрозу» автор систематично відстоює й інтереси Русі-України у складі Речі Посполитої. У «Квінкунксі» Оріховський наголошує на тому, що він поляк, хоча має на увазі польське громадянство. Пише, що хоче служити своєму польському народові всім серцем і душею. Можна спостерігати певний суттєвий злам у настроях автора, його спольщення, що стало результатом кризових настроїв наприкінці життя. Водночас, коли звертається до коронних послів із Варшави, то пише, що він «брат ваш з Русі». Русь він бачить у складі Польської держави, а найбільшою загрозою ії єдності вважає розбрат домовий, викликаний несправедливим ставленням до інших народів, зокрема руського. Себе Оріховський вважав зразковим підданим Речі Посполитої. Він $є$ письменником польсько-українського контексту, хоча Вітчизною незмінно називав Русь.

Отже, художні тлумачення національної ідентифікації у добу українського літературного Ренесансу базувалися на усвідомленні таких складових, як територія, мова, релігія, держава. Визначальне значення для митців мало етнічне походження з Русі-України та систематичне звернення до української тематики. Представники католицької Русі усвідомлювали тяглість державно-історичної традиції, називаючи Київську Русь державним утворенням саме українського народу. Перехід у католицьку віру не означав зради українського народу. Віра бачилася як кращий спосіб служіння йому i захисту. Загалом українцями були всі мешканці українських (руських) землі, а «з погляду такої національної ідеології, «католицька Русь» для культури української зробила, певно, не менше, ніж греко-католики чи й православні, і випродукувала, може, не менше, ніж вони, культурних сил як для української матеріальної культури, так і для української культури духовної» [1, с. 362]. Це була латиномовна література, яка суттєво вплинула на духовно-культурну переорієнтацію Україна 3 Візантії на Європу. Її представники розповідали Європі про Русь-Україну, ідентифікуючи себе як русів-українців, дбаючи про інтереси Вітчизни.

\section{ЛІТЕРАТУРА}

1. Литвинов В. Д. Ренесансний гуманізм в Україні. Ідеї гуманізму епохи Відродження в українській філософії XV - початку XVII століття. Київ : Основи, 2000. 472 с.

2. Литвинов В. Д. Україна у пошуках своєї ідентичності. XVI - початок XVII ст. Історикофілософський нарис / В. Д. Литвинов. Київ. : Наукова думка, 2008. 527 с.

3. Українські гуманісти епохи Відродження. Антологія : у 2 частинах. Частина 1 / відп ред. В. М. Нічик. Київ : Наукова думка, 1995. 430 с.

4. Українські гуманісти епохи Відродження. Антологія : у 2 частинах. Частина 2 / відп ред. В. М. Нічик. Київ : Наукова думка, 1995. 431 с.

5. Наливайко Д. С. Очима Заходу : Рецепція України в Західній Європі XI-XVIII ст. / Д. С. Наливайко. Київ : Грамота, 2008. 784 с.

6. Шевчук В. О. Муза Роксоланська. Ренесанс. Раннє Бароко. Кн. 1. Київ : Наук. думка, 2004. $397 \mathrm{c}$. 
7. Слово Многоцінне. Хрестоматія української літератури, створеної різними мовами в епоху Ренесансу (друга половина XV - XVI століття) та в епоху Бароко (кінець XVI - XVII століття) / упор. В. Яременко, В. О. Шевчук ; керівник проекту В. Яременко. Кн. 1. Київ : Аконіт, 2006. 799 с.

\section{REFERENCES}

1. Lytvynov, V.D. (2000), Renaissanse humanism in Ukraine. Ideas of the humanism of Renaissance in the Ukrainian philosophy of the $15^{\text {th }}$ - early $17^{\text {th }}$ century [Renesansnyi humanizm $v$ Ukraini. Idei humanizmu epokhy Vidrodzhennia v ukrainskii filosofii XV - pochatku XVII stolittia], Osnovy, Kyiv, 472 p. (in Ukrainian)

2. Lytvynov, V.D. (2008), Ukraine is in search of its identity. $16^{\text {th }}$ - early $17^{\text {th }}$ century. Historical and philosophical essay [Ukraina u poshukakh svoiei identychnosti. XVI - pochatok XVII st. Istoryko-filosofskyi narys], Naukova dumka, Kyiv, 527 p. (in Ukrainian)

3. Nalyvaiko, D.S. (2008), The West's eyes: reception of Ukraine in Western Europe during $11^{\text {th }}$ $18^{\text {th }}$ centuries [Ochyma Zakhodu: Retseptsiya Ukrainy v Zakhidnii Yevropi XI - XVIII st.], Hramota, Kyiv, 784 p. (in Ukrainian)

4. Nichyk, V.M. (Ed.). (1995), Ukrainian humanists of the Renaissance: in 2 b. B.1 [Ukrainski humanisty epokhy Vidrodzhennia: u 2 kn. Kn. 1], Naukova dumka, Kyiv, 430 p. (in Ukrainian)

5. Nichyk, V.M. (Ed.). (1995), Ukrainian humanists of the Renaissance: in 2 b. B.2 [Ukrainski humanisty epokhy Vidrodzhennia: $u 2$ kn. Kn. 2], Naukova dumka, Kyiv, 431 p. (in Ukrainian)

6. Shevchuk, V.O. (2004), Roksolanska muse. Renaissance. The early Baroque style: in 2 b. B. 1 [Muza Roksolanska. Renesans. Rannie Baroko: u 2 kn. Kn. 1], Naukova dumka, Kyiv, 397 p. (in Ukrainian)

7. Yaremenko, V.V. and Shevchuk, V.O. (2006), in Yaremenko, V. V. (Ed.), The word is of great value. The chrestomathy of Ukrainian literature written in different languages during both Renaissance (second half of $15^{\text {th }}-16^{\text {th }}$ century) and Baroque era (the end of $16^{\text {th }}-17^{\text {th }}$ century): in 4 b. B. 1 [Khrestomatiia ukrainskoi literatury, stvorenoi riznymy movamy $v$ epokhu Renesansu (druha polovyna XV - XVI stolittia) ta v epokhu Baroko (kinets XVI - XVII stolittia): u 4 kn. Kn. 1], Akonit, Kyiv, 799 p. (in Ukrainian)

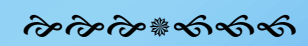

